\title{
Suspension feeding on phytoplankton by Solemya velum, a symbiont-containing clam
}

\author{
Dana M. Krueger ${ }^{1}$, Scott M. Gallager ${ }^{2, *}$, Colleen M. Cavanaugh ${ }^{1}$ \\ ${ }^{1}$ Harvard University, Department of Organismic and Evolutionary Biology, Biological Laboratories, 16 Divinity Avenue, \\ Cambridge, Massachusetts 02138, USA \\ ${ }^{2}$ Biology Department, Woods Hole Oceanographic Institution, Woods Hole, Massachusetts 02543, USA
}

\begin{abstract}
Solemya velum Say, a bivalve found in coastal sediments along eastern North America, is known to harbor chemoautotrophic symbionts in its gill tissue. These intracellular bacteria are thought to contribute significantly to the nutrition of the host. S. velum's behavior, however, suggests that it may feed on suspended particles. The ingestion of ${ }^{14} \mathrm{C}$-labeled phytoplankton (Isochrysis galbana, Dunaliella tertiolecta, and Synechococcus sp.) by S. velum was compared to Mya arenaria, a suspension-feeding bivalve that is not associated with symbionts. S. velum ingested only the smallest food particles (Synechococcus sp.) in detectable amounts. The number of cells ingested, however, averaged only about half that taken up by $M$. arenaria under identical experimental conditions. It is hypothesized that the symbiotic clam $S$. velum does not ingest particles for bulk nutrition, but may depend on a small amount of phytoplankton for essential nutrients available only from exogenous sources.
\end{abstract}

\section{INTRODUCTION}

Questions relating to the nutrition of marine invertebrates which harbor chemoautotrophic symbionts have abounded since the initial description of such associations in deep-sea hydrothermal vent organisms. With the discovery of symbiotic chemoautotrophs in the vestimentiferan tubeworm Riftia pachyptila, it was hypothesized that the symbionts could function as an internal source of nutrition to the host (Cavanaugh et al. 1981, Felbeck 1981). Symbioses between invertebrates and chemoautotrophic bacteria have since been found to occur commonly in the marine environment, and have been documented in at least 4 different phyla (see review in Fisher 1990). As chemoautotrophs, the symbionts fix $\mathrm{CO}_{2}$ via the Calvin-Benson cycle and use reduced inorganic sulfur compounds such as sulfide as energy sources. The organic compounds synthesized by the bacteria are thought to be subsequently translocated to the host, as has been shown for the gutless bivalve Solemya reidi (Fisher \& Childress 1986). Stable isotope signatures of host tissues also suggest that the symbionts function trophically in chemoautotrophic symbioses (see review in Fisher 1990).

- Present address: Department of Biology, Dalhousie University, Halifax, Nova Scotia, Canada B3H 4J1
The nutritive needs of the protobranch bivalve Solemya velum Say, which has been studied as a shallowwater model of chemoautotroph-invertebrate associations, are also thought to be met almost exclusively by carbon translocated from its symbionts. Stable isotope and biomarker analyses, for example, have provided strong support for the hypothesis that the bacteria are nutritionally important to the host (Conway et al. 1989, Conway \& McDowell Capuzzo 1991). On the other hand, $S$. velum has a gut which is small but apparently functional (Yonge 1939), and the relative contribution of exogenous organic material to the symbiosis remains to be assessed (Cavanaugh 1985a, Conway et al. 1989. Conway \& McDowell Capuzzo 1991).

Classified as a protobranch, Solemya velum was originally thought to be a deposit feeder (Yonge 1939). Its labial palps are too short to extend outside of the shell, however, and therefore make the ingestion of sediment an unlikely feeding strategy (Levinton 1977). On the basis of observations that this clam normally lives in Y-shaped burrows in the sediment, actively pumping water through the burrow while positioned in the cradle of the ' $\mathrm{Y}$ ', it was suggested that perhaps $S$. velum is a suspension feeder and ingests particles entrained in the incoming current (Stanley 1970). Indeed, fine-grained particles have been observed in the guts of dissected specimens of $S$. velum, indicating 
that ingestion of particulate organic matter is at least possible (Levinton 1977). This study examines the suspension-feeding capabilities of $S$. velum in comparison with Mya arenaria, a known filter-feeding bivalve from the same habitat, and assesses the relative contribution of particulate food to the nutrition of the $S$. velumbacteria symbiosis.

\section{MATERIALS AND METHODS}

Experimental animals. Solemya velum and Mya arenaria of similar size were collected from eelgrass beds near Woods Hole, Massachusetts, USA. The clams were stored under running seawater in containers of silty sediment obtained from the collection site. All clams were used for experimentation within $48 \mathrm{~h}$ of collection. About $1 \mathrm{~h}$ before an experiment, each clam was rinsed thoroughly and placed in $0.2 \mu \mathrm{m}$ filtered seawater (FSW). Clams used as negative controls were preserved in $10 \%$ formalin in seawater overnight.

Wet to dry wt conversions were determined for both clam species. Tissues were dissected, and weighed before and after drying at $60^{\circ} \mathrm{C}$ for at least $48 \mathrm{~h}$. The gills of Solemya velum were removed and analyzed separately as per the feeding experiments (see below). By regressing dry against wet wt of the excised tissue, it was found that the gills of $S$. velum were ca $24 \%$ water $\left(a=0.243, b=-1.385 \times 10^{-4}, \mathrm{n}=14, \mathrm{r}^{2}=0.98\right)$. A similar regression analysis on the remaining tissue revealed that it was about $27 \%$ water by weight ( $a=$ $0.274, b=-9.758 \times 10^{-4}, n=14, r^{2}=0.98$ ). The Mya arenaria samples had just over $15 \%$ water in all tissues combined $\left(a=0.155, b=1.114 \times 10^{-2}, \mathrm{n}=13, \mathrm{r}^{2}=\right.$ $0.96)$. These conversions were used throughout the data set to express all rates per gram dry weight $\left(\mathrm{g}^{-1}\right.$ dw) of clam.

Suspension feeding on phytoplankton. Three species of phytoplankton typical of the habitat in which Solemya velum lives were cultured, radiolabeled with $\mathrm{NaH}^{14} \mathrm{CO}_{3}$ and used to measure particle ingestion rates. The marine algae Isochrysis galbana (strain $\mathrm{T}$ ISO, diameter ca $4 \mathrm{\mu m}$ ) and Dunaliella tertiolecta (diameter ca $14 \mu \mathrm{m}$ ) were grown in flasks of pasteurized f/2 media (Guillard 1975) at $22^{\circ} \mathrm{C}$ on a $12: 12$ light:dark cycle. The cyanobacterium Synechococcus $\mathrm{sp}$. (strain WH8301, diameter ca $1 \mu \mathrm{m}$ ) was grown at $22^{\circ} \mathrm{C}$ under constant, dim light in flasks of pasteurized SN media (Waterbury et al. 1986). Ca $2 \mathrm{~d}$ after the start of a new culture, $50 \mu \mathrm{Ci} \mathrm{NaH}{ }^{14} \mathrm{CO}_{3}$ per $500 \mathrm{ml}$ phytoplankton suspension was added. The cells were harvested 4 to 6 d later in a table-top centrifuge $(3000 \times g$ for $10 \mathrm{~min})$, washed twice with FSW, and resuspended in FSW to a final volume of $50 \mathrm{ml}$. In stock solutions, multiple haemacytometer counts $(n=8)$ were used to determine the concentrations of $I$. galbana and $D$. tertiolecta. Synechococcus sp. cell concentrations were determined by direct cell counts on a Zeiss epifluorescence microscope (Waterbury et al. 1986), Specific activities, determined for $1 \mathrm{ml}$ subsamples of a known concentration of cells, were: $0.18 \mathrm{dpm}$ cell $^{-1}$ for $I$. galbana, $0.001 \mathrm{dpm}^{-1} \mathrm{ll}^{-1}$ for Synechococcus sp. and $0.6 \mathrm{dpm} \mathrm{cell}^{-1}$ for $D$. tertiolecta.

To quantify the ingestion of phytoplankton by Solemya velum, removal rates as well as the incorporation of ${ }^{14} \mathrm{C}$ into animal tissue were determined. Fresh formalin-killed clams served as negative controls, while live Mya arenaria were used as positive experimental controls, since this species is known to ingest phytoplankton (Jørgensen 1990).

Two beakers, one for live and one for dead clams, were prepared for both Mya arenaria and Solemya velum in each experiment. Phytoplankton concentrations for each experiment were chosen to reflect the typical concentration of algae and cyanobacteria in coastal environments (Waterbury et al. 1986) and to maintain a roughly constant phytoplankton biomass between treatments. The initial concentrations for experiments were as follows: Isochrysis galbana, $4 \times$ $10^{4}$ cells ml ${ }^{-1}$; Dunaliella tertiolecta, $3 \times 10^{4}$ cells ml $^{-1}$; and Synechococcus sp., $1 \times 10^{5}$ cells $\mathrm{ml}^{-1}$. All beakers were covered and gently aerated throughout the experiments. Triplicate $1 \mathrm{ml}$ water samples were taken at $0,2,4,8$ and $12 \mathrm{~h}$ after the start of an experiment, and the amount of radiolabel left in each sample determined in order to quantify the removal rates of each species of phytoplankton tested. The water samples were added directly to $7 \mathrm{ml}$ scintillation vials containing $5 \mathrm{ml} \mathrm{Ready} \mathrm{Solve} \mathrm{Scintillant} \mathrm{and} \mathrm{counted} \mathrm{on} \mathrm{a}$ Packard MINAXI $\beta$ Tri-carb 4000 scintillation counter after $24 \mathrm{~h}$ in the dark to reduce chemiluminescence. The external standard method was used for quench correction. After $12 \mathrm{~h}$, the clams were placed in unlabeled food suspensions for an additional $12 \mathrm{~h}$ to ensure that only ingested cells would be detected in the tissue analyses.

At the end of the experiment, the clams were rinsed and quickly dissected, and the tissues frozen in liquid nitrogen and stored at $-20{ }^{\circ} \mathrm{C}$ until they could be processed for liquid scintillation counting. None of the samples were stored longer than $72 \mathrm{~h}$. The thick, fleshy gills of the Solemya velum samples were separated from the rest of the tissue upon dissection in order to simplify sample processing, while the bodies of Mya arenaria were small enough to be left whole.

The frozen tissues were homogenized in $0.1 \mathrm{~N} \mathrm{NaOH}$ in conical glass tissue grinders until a uniform suspension was obtained. Aliquots $(300 \mu \mathrm{l}, \mathrm{n}=3$ ) of the homogenates were added directly to $5 \mathrm{ml}$ of Ready Solve Scintillant and counted as above. 
Because experiments on clams burrowed into sediment proved logistically impossible, an examination of the feeding behavior of both Solemya velum and Mya arenaria under the experimental conditions was conducted. To ensure that both species can actively pump water (and food) while out of the mud, freshly collected clams were placed in a plastic petri dish with FSW at room temperature and their excurrent flow fields observed with dark field illumination on a Zeiss dissecting microscope. In addition to $4 \times 10^{4}$ cells ml $^{-1}$ of Isochrysis galbana, a small amount of polystyrene bead mixture $(0.2$ to $30 \mu \mathrm{m}$ diameter), rinsed free of surfactant, was added to the petri dish to aid in visualizing the excurrent flow fields of individual clams. Observation of the flow fields of both species indicated that they were vigorously pumping under these conditions ( $S$. velum: $\mathrm{n}=6 ; M$. arenaria: $\mathrm{n}=8$ ). Furthermore, $S$. velum has been shown to respire and fix carbon dioxide in the presence of reduced sulfur compounds at maximal rates comparable to bivalves of similar size and free-living chemoautotrophs, respectively, under these conditions (Cavanaugh 1985b). Hence, the measurements made in this study are representative of these species' feeding potentials in nature.

Uptake of dissolved carbon. The possibility that dissolved labeled carbon could have leached from the phytoplankton during the experiment due to leaky membranes and/or algal respiration, and that the activity detected in the Solemya velum tissue could have been due to the uptake of dissolved ${ }^{14} \mathrm{C}$ rather than particle ingestion was also considered. In order to test this hypothesis, the feeding experiments were repeated, using the filtrate of ${ }^{14} \mathrm{C}$-labeled phytoplankton cells in place of the actual food particles.

Isochrysis galbana and Synechococcus sp. cultures were labeled with ${ }^{14} \mathrm{C}$ as per the ingestion experiments, with final specific activities of $0.001 \mathrm{dpm} \mathrm{cell}^{-1}$ for Synechococcus sp. and $0.105 \mathrm{dpm} \mathrm{dell}^{-1}$ for 1 . galbana. Both algal species were incubated in aerated FSW overnight at concentrations similar to those used in the feeding experiments: $4 \times 10^{4} \mathrm{I}$. galbana cells $\mathrm{ml}^{-1}$ and $1 \times 10^{5}$ Synechococcus sp. cells $\mathrm{ml}^{-1}$. Each suspension was then filtered through a $0.45 \mu \mathrm{m}$ filter, and the filtrates sampled for ${ }^{14} \mathrm{C}$ counts. Live and dead clams were incubated in the ${ }^{14} \mathrm{C}$ filtrate for $12 \mathrm{~h}$, followed by $12 \mathrm{~h}$ in unlabeled food suspensions. Incorporation rates, expressed as cells $\mathrm{g}^{-1} \mathrm{dw} \mathrm{h}^{-1}$, were calculated from the corresponding tissue analyses and compared to the measured particle ingestion data.

\section{RESULTS}

Removal of phytoplankton from seawater by Solemya velum was strikingly low in comparison to Mya arenaria, a known suspension feeder (Fig. 1). No difference between the dead controls and $S$. velum samples was detected over the course of the experiment for any of the 3 food types, according to a Tukey

a) Synechococcus sp.

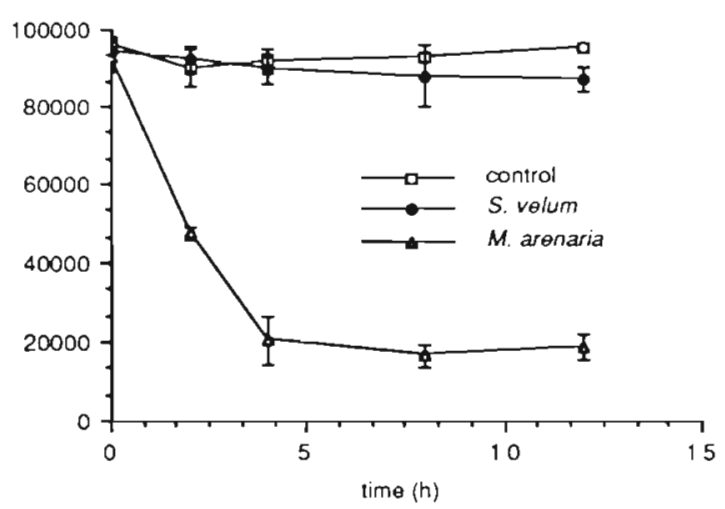

b) Isochrysis galbana

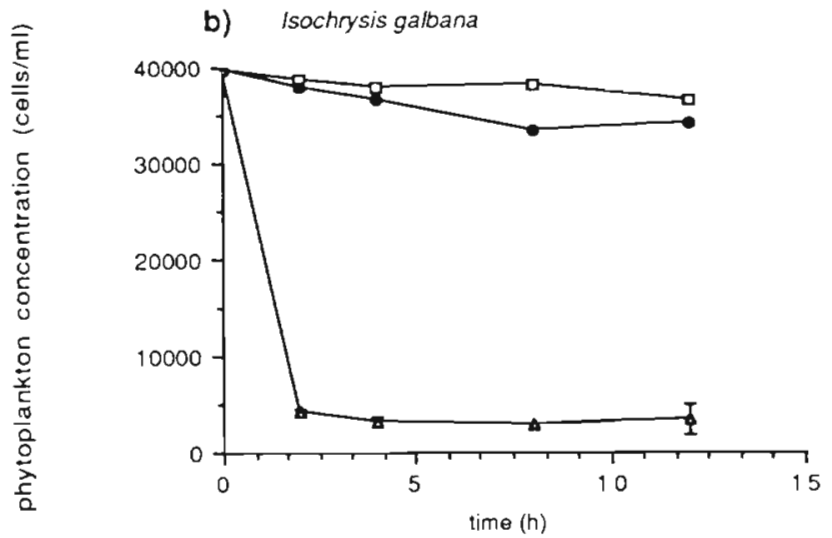

c) Dunaliella tertiolecta

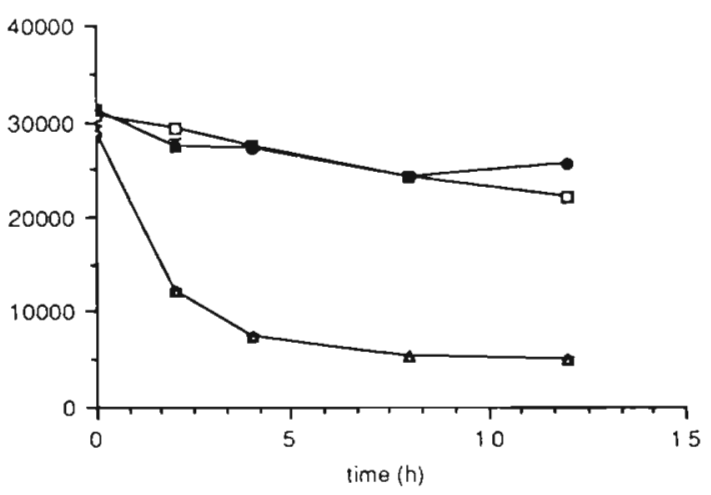

Fig. 1. Solemya velum and Mya arenaria. Removal of (a) Synechococcus sp., (b) Isochrysis galbana and (c) Dunaliella tertiolecta by $S$. velum $(\mathrm{n}=4$ for each food type, mean length = $13.8 \pm 2.2 \mathrm{~mm}$ ) and $M$. arenaria ( $\mathrm{n}=4$ for each food type, mean length $=18.7 \pm 2.1 \mathrm{~mm})$. Dead clams $(n=4)$ served as controls, and triplicate samples were taken within each treatment. Data are mean cell concentrations $\pm \mathrm{SD}$ 
multiple comparisons test on the rates of cell removal calculated from the first $2 \mathrm{~h}$ of the experiment in the case of Isochrysis galbana, and the first $4 \mathrm{~h}$ for the other 2 foods $(p<0.05)$. In marked contrast to $S$. velum, $M$. arenaria depleted at least $75 \%$ of the suspended particles within $4 \mathrm{~h}$ for all 3 food types. A noticeable change in color due to the removal of suspended phytoplankton took place during that time, and the appearance of fecal pellets was noted within the beakers containing $M$. arenaria, but not in the beakers containing $S$. velum.

Incorporation of ${ }^{14} \mathrm{C}$-labeled carbon from phytoplankton into tissue was consistent with cell removal patterns, but indicate that Solemya velum did ingest some Synechococcus sp. (Fig. 2). The average incorporation rates of Isochrysis galbana and Dunaliella tertiolecta by $S$. velum, $3.1 \times 10^{4}$ and $2.5 \times 10^{5}$ cells $g^{-1} \mathrm{dw}$ $\mathrm{h}^{-1}$ respectively, were significantly lower than those by Mya arenaria, $3.8 \times 10^{7} \mathrm{I}$. galbana cells $\mathrm{g}^{-1} \mathrm{dw}^{-1}$ and $5.3 \times 10^{7} \mathrm{D}$. tertiolecta cells $\mathrm{g}^{-1} \mathrm{dw} \mathrm{h}^{-1}$ (Tukey multiple comparisons test on control-corrected data, $\mathrm{p}<0.05$ ). In contrast, Synechococcus sp. was incorporated significantly by both clam species (Tukey multiple comparisons test on control-corrected data, $p<0.05$ ), but $S$. velum averaged only $3.5 \times 10^{7}$ cells $\mathrm{g}^{-1} \mathrm{dw} \mathrm{h}^{-1}$, about half the rate recorded for $M$. arenaria (Fig. 2a).

Since the radiolabeled carbon detected in Solemya velum could possibly have been incorporated from the dissolved carbon leaking from the ${ }^{14} \mathrm{C}$-labeled phytoplankton, clams were incubated in filtrates from radiolabeled cell suspensions and assayed for radioactivity. Labeled carbon was detected in the initial filtrate $(250$ dpm $\mathrm{ml}^{-1}$ ) from the Isochrysis galbana suspension, as well as in the tissues of $S$. velum ( $>200 \mathrm{dpm} \mathrm{clam}^{-1}$ ) after being incubated in this filtrate. An incorporation rate (cells $\mathrm{g}^{-1} \mathrm{dw} \mathrm{h}^{-1}$ ) was then calculated on the basis of the tissue activity and specific activity of the phytoplankton, and compared to the measured rate of $I$. galbana cell incorporation (Fig. 3a). The measured and apparent incorporation rates of 1 . galbana cells were significantly different from the control values (2-way ANOVA, $F_{1,12}=40.4, p \leq 0.0001$ ); therefore, we were unable to determine whether the activity detected in $S$. velum in the ${ }^{14} \mathrm{C}$-labeled $I$. galbana feeding studies was due to incorporation of phytoplankton or dissolved carbon.

In contrast, little activity was detected in the Synechococcus sp. filtrate $\left(<10 \mathrm{dpm} \mathrm{ml}^{-1}\right)$, indicating that Synechococcus sp. does not leak large amounts of dissolved carbon, as has been shown previously by Waterbury et al. (1986). Furthermore, the activity detected in the tissues of clams incubated in this filtrate was not significantly different from either the measured or apparent rates of incorporation for the dead animal
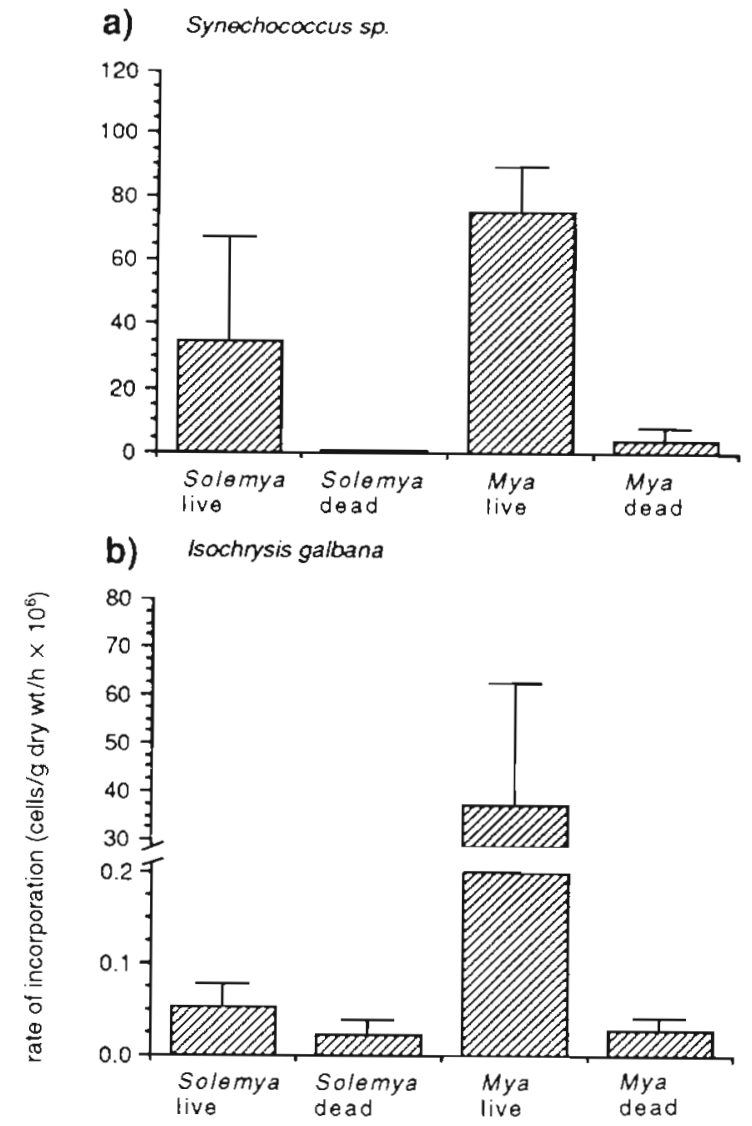

c) Dunaliella tertiolecta

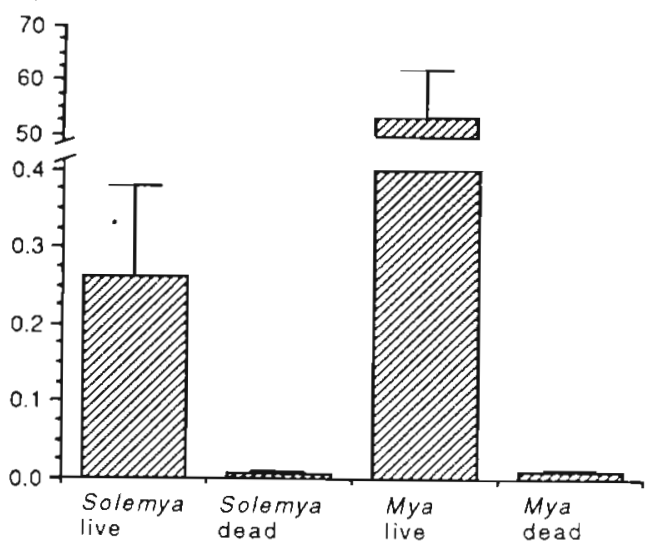

Fig. 2. Solemya velum and Mya arenaria. Incorporation of carbon from ${ }^{14} \mathrm{C}$-labeled (a) Synechococcus sp., (b) Isochrysis galbana and (c) Dunaliella tertiolecta after $12 \mathrm{~h}$. Dead clams served as controls. Data are means $+1 \mathrm{SD}(\mathrm{n}=4)$

controls (Fig. 3b). The incorporation rate measured with this food differed significantly from the other values (Tukey multiple comparisons test, $p<0.05$ ). Hence, the activity detected in the tissue of clams fed labeled Synechococcus $\mathrm{sp}$. represents true particle ingestion rather than uptake of labeled dissolved carbon. 

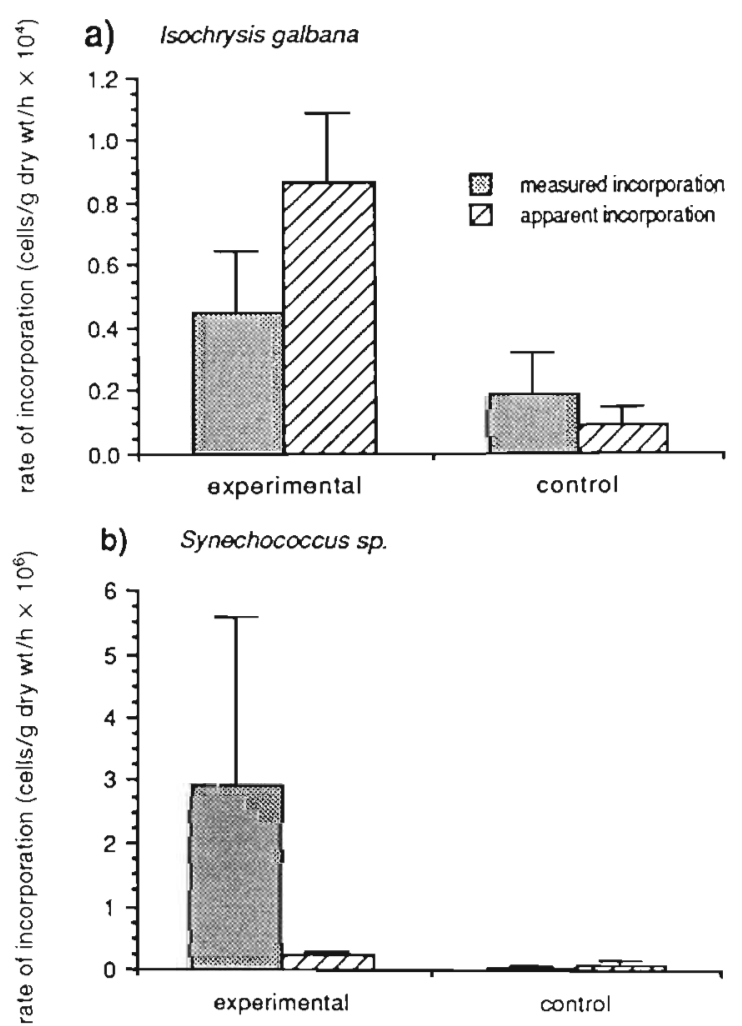

Fig. 3. Solemya velum. Measured and apparent incorporation rates of (a) Isochrysis galbana and (b) Synechococcus sp. when exposed to ${ }^{14} \mathrm{C}$-labeled particles and ${ }^{14} \mathrm{C}$-labeled particle filtrate. Apparent ingestion rates were calculated from data derived from radiolabeled dissolved carbon uptake experiments. Dead animals served as controls. Values shown are means $+1 \mathrm{SD}(\mathrm{n}=4)$

\section{DISCUSSION}

Solemya velum, one species of protobranch bivalve which harbors dense populations of chemaautotrophic bacteria in its gills, also possesses a functional digestive system (Yonge 1939, Levinton 1977). With a series of experiments designed to investigate the suspensionfeeding capabilities of $S$. velum, we found that this species does not rely on the ingestion of suspended particles for the bulk of its nutrition. Isochrysis galbana and Dunaliella tertiolecta are nutritious green algae found in coastal Atlantic waters and are readily eaten by benthic suspension feeders such as Mya arenaria (Romberger \& Epifanio 1981, this study), but negligible amounts of these same algae were ingested by $S$. velum in our laboratory experiments (Figs. 1 \& 2). On the other hand, both $S$. velum and $M$. arenaria were shown to ingest the cyanobacteria Synechococcus sp. in significant amounts. The rate at which the symbiotic bivalves took up Synechococcus sp., however, averaged only about half the rate observed for $M$. arenaria (Fig. 2a). We conclude that a small amount of particle ingestion occurs in S. velum, and is a probable source of essential nutrients for the host.

Why Solemya velum ingests smaller (i.e., Synechococcus sp.) versus larger (i.e. Isochrysis galbana, Dunaliella tertiolecta) marine particles, however, remains unclear. A study on the feeding capabilities of a symbiont-containing mytilid (as yet unnamed) from hydrocarbon seeps revealed that this bivalve also ingested ca $1 \mu \mathrm{m}$ sized particles at a disproportionately higher rate than larger cells (Page et al. 1990). It was suggested that this species of mussel maintains a high retention efficiency for small particles since the deepsea habitat in which it lives is rich in free-living bacteria (Page et al. 1990). However, S. velum accurs in productive coastal habitats where green algal species are abundant (Stanley 1970), and no incorporation of these types of cells was measured. The relative inefficiency of $S$. velum at ingesting suspended particles may also be related at least in part to its typical protobranch gill morphology. S. velum lacks the highly specialized gill cilia for food particle transport, capture and ingestion characteristic of other suspension feeders such as mytilid bivalves and the eulamellibranch Mya arenaria (Barnes 1988, Jørgensen 1990). Hence, it seems that qualitative differences among particles and the primitive morphology of the solemyid gill may affect ingestion rates in $S$. velum, although the specific mechanism of selective feeding is not yet known.

Given that Solemya velum is capable of removing and ingesting at least some small particles (i.e. Synechococcus sp.) from the overlying water, an estimation of the potential importance of suspension feeding to the overall nutrition of $S$. velum can be made. As direct respiration measurements of $S$. velum are difficult owing to the simultaneous oxidation of sulfide by the symbionts, the carbon requirement for $S$. velum can be estimated from oxygen consumption rates of Yoldia limatula, another protobranch bivalve that lives in habitats where $S$. velum occurs but that lacks gill symbionts (Cavanaugh 1985a). The carbon requirement of a $0.025 \mathrm{~g} \mathrm{dw}$ S. velum is estimated at $5.81 \mu \mathrm{g} \mathrm{C}$ ind. ${ }^{-1}$ $\mathrm{h}^{-1}$, based on the measured respiratory requirement for $Y$. limatula of $6.05 \mu \mathrm{g} \mathrm{C}$ ind. ${ }^{-1} \mathrm{~h}^{-1}$ for a $0.026 \mathrm{~g} \mathrm{dw}$ clam. The measured incorporation rate of Synechococcus $\mathrm{sp}$. cells, $3.5 \times 10^{7}$ cells g ${ }^{-1} \mathrm{dw} \mathrm{h}^{-1}$, translates to $0.25 \mu \mathrm{g} \mathrm{C}$ ind. $^{-1} \mathrm{~h}^{-1}$, given that each Synechococcus sp. cell contains $0.29 \mathrm{pg} \mathrm{C}$ (Waterbury \& Cuhel 1984). With an assimilation efficiency of 0.6 , a typical estimate for invertebrates feeding on single-celled organisms (Valiela 1984, Page et al. 1990, Gallager et al. 1992), an individual clam would assimilate $0.15 \mu \mathrm{g} \mathrm{Ch}^{-1}$. Hence, only $3 \%$ of the respiratory carbon budget of $S$. velum could be met by the ingestion of Synechococcus sp. at a typical concentration of $10^{5}$ cells $\mathrm{ml}^{-1}$.

These calculations further support the hypothesis 
that Solemya velum, like its symbiotic relatives Solemya reidi and Solemya borealis, is primarily dependent on symbiont-produced organic carbon for its nutrition (Conway et al. 1989, 1992). This is in contrast to other marine symbioses that rely heavily on heterotrophic feeding. For example, it has been shown that the giant clam Tridacna gigas uses a combined input from its endosymbiotic zooxanthellae and suspension feeding to support the host both in respiration and growth (Klumpp et al. 1992). Similarly, corals have long been known to feed on plankton in addition to metabolizing photosynthate from their symbionts (Lewis 1977). Furthermore, in some hosts which harbor chemoautotrophic symbionts and have the ability to feed, suspension feeding supplements their internal nutritional source. The seep mussel having methanotrophic symbionts, for example, relies on suspension feeding as an additional source of both carbon and nitrogen (Page et al. 1990).

In other bivalve-chemoautotroph symbioses such as Solemya velum, the ingestion of phytoplankton is thought to provide certain polyunsaturated fatty acids (PUFAs) which are essential to all marine bivalves (Conway \& McDowell Capuzzo 1991). These particular fatty acids are synthesized by phytoplankton and higher plants; the vast majority of bacteria studied to date are incapable of PUFA synthesis (Goldfine 1972, Phillips 1984). Hence, ingestion of phytoplankton is a likely source of PUFAs for the $S$. velum symbiosis. Still, the question remains whether chemoautotrophic symbionts are able to synthesize these compounds, since some of the invertebrates harboring such bacteria completely lack a mouth and gut (see review in Fisher 1990).

The low rates of particle ingestion found for Solemya velum indicate that this species does not rely on suspension feeding, thereby providing further support for the hypothesis that the intracellular bacteria function trophically in this symbiosis. Some ingestion of small particles occurs in $S$. velum, however, and is a probable source of essential nutrients for the host. That is, $S$. velum's limited capacity for suspension feeding appears to nutritionally complement its symbiotic condition. Particle ingestion rates for invertebratechemoautotroph symbioses, given that some host species can feed while others completely lack a mouth and gut, likely reflect the degree to which the host depends on its endosymbionts for nutrition and the extent of coevolution within each association.

Acknowledgements. We thank Noellette Conway, Freddie Valois, and Linda Davis for their help in setting up phytoplankton cultures, equipment use, and many insightful discussions. Heather Leslie is acknowledged for her technical assistance. This work was supported by NSF Grant OCE 89-11844 (S.M.G.) and by NSF Grant DCB 87-18799 (C.M.C.).

\section{LITERATURE CITED}

Barnes, R. D. (1988). Invertebrate zoology, 5th edn. Saunders College Publishing, New York

Cavanaugh, C. M., Gardiner, S. L., Jones, M. L., Jannasch, H. W., Waterbury, J. B. (1981). Prokaryotic cells in the hydrothermal vent tube worm Riftia pachyptila Jones: possible chemoautotrophic symbionts. Science 213: $340-342$

Cavanaugh, C. M. (1985a). Symbioses of chemoautotrophic bacteria and marine invertebrates from hydrothermal vents and reducing sediments. Biol. Soc. Wash. Bull. 6: $373-388$

Cavanaugh, C. M. (1985b). Symbiosis of chemoautotrophic bacteria and marine invertebrates. Ph.D. thesis, Harvard Univ.

Conway, N. M., Howes, B. L., McDowell Capuzzo, J. E., Turner, R. D., Cavanaugh, C. M. (1992). Characterization and site description of Solemya borealis (Bivalvia; Solemyidae), another bivalve-bacteria symbiosis. Mar. Biol. 112 $601-613$

Conway, N. M., McDowell Capuzzo, J. (1991). Incorporation and utilization of bacterial lipids by the Solemya velum symbiosis. Mar. Biol. 108: 277-291

Conway, N. M., McDowell Capuzzo, J., Fry, B. (1989). Role of endosymbiotic bacteria in the nutrition of Solemya velum: evidence from stable isotope analyses of endosymbionts and host. Limnol. Oceanogr. 34 (1): 249-255

Felbeck, H. (1981). Chemoautotrophic potential of the hydrothermal vent tube worm, Riftia pachyptila Jones (Vestimentifera). Science 213: 336-338

Fisher, C. R. (1990). Chemoautotrophic and methanotrophic symbioses in marine invertebrates. Rev. aquat. Sci. $2(3-4)$ : 399-436

Fisher, C. R., Childress, J. J. (1986). Translocation of fixed carbon from symbiotic bacteria to host tissues in the gutless bivalve Solemya reidi. Mar. Biol. 93: 59-68

Gallager, S. M., Stoecker, D. K., Waterbury, J. B. (1992) Efficient capture, ingestion, and assimilation of Synechococcus sp. by larvae of a marine bivalve mollusc. Mar. Biol, in press

Goldfine, H. (1972). Comparative aspects of bacterial lipids. Adv. microb. Physiol. 8: 1-58

Guillard, R. R. L. (1975), Culture of phytoplankton for feeding marine invertebrates. In: Smith, W. L., Chanley, M. H. (eds.) Culture of marine invertebrate animals. Plenum Press, New York, p. 29-60

Jørgensen, C. B. (1990). Bivalve filter feeding: hydrodynamics, bioenergetics, physiology and ecology. Olsen and Olsen, Fredensborg

Klumpp, D. W. Bayne, B. L., Hawkins, A. J. S. (1992). Nutrition of the giant clam Tridacna gigas (L.). I. Contribution of filter feeding and photosynthates to respiration and growth. J. exp. mar Biol. Ecol. 135: 105-122

Levinton, J. S. (1977). Ecology of shallow water deposit-feeding communities: Quisset Harbor, Massachusetts. In Coull, B. C. (ed.) Ecology of marine benthos. Univ. South Carolina Press, Columbia, p. 191-228

Lewis, H. B. (1977). Experimental tests of suspension feeding on Atlantic reef corals. Mar Biol. 36: 147-150

Page, H. M., Fisher, C. R., Childress, J. J. (1990). Role of filter-feeding in the nutritional biology of a deep-sea mussel with methanotrophic symbionts. Mar Biol. 104: 251-257

Phillips, N. W. (1984). The role of different microbes and substrates as potential suppliers of specific, essential nutrients to marine detritivores. Bull. mar. Sci. 35: 283-298 
Romberger, H. P., Epifanio, C. E. (1981). Comparative effects of diets consisting of one or two algal species upon assimilation efficiences and growth of juvenile oysters, Crassostrea virginica (Gmelin). Aquaculture 25: 77-87

Stanley, S. M. (1970). Relation of shell form to life habits of the Bivalvia (Mollusca). Mem. geol. Soc. Am. 125: 1-296

Valiela, I. (1984). Marine ecological processes. SpringerVerlag, New York

Waterbury, J. B. Cuhel, R. L. (1984). Biochemical composition and short-term nutrient incorporation patterns in a uni-

This article was presented by J. M. Shick, Orono, Maine, USA cellular marine cyanobacterium, Synechococcus (WH 7803). Limnol. Oceanogr. 29: 370-374

Waterbury, J. B., Watson, S. W., Valois, F. W., Franks, D. G. (1986). Biological and ecological characterization of the marine unicellular cyanobacterium Synechococcus. In: Platt. T., Li, W K. W (eds.) Photosynthetic picoplankton. Can. Bull. Fish. Aquat. Sci. 214: 71-120

Yonge, C. M. (1939). The protobranchiate mollusca; a functional interpretation of their structure and evolution. Phil. Trans. R. Soc. (Ser. B) 230: 79-147

Manuscript first received: April 24, 1992 Revised version accepted: July 15, 1992 